\title{
PENERAPAN MEDIA WHATSAPP GROUP DAN LINOIT DALAM MENINGKATKAN HASIL BELAJAR PENGELOLAAN KAS
}

\section{Sri Kartini}

Sekolah Menengah Kejuruan (SMK) Negeri 1 Singkep, Kepulauan Riau, Indonesia Email: jasminpasaka12@gmail.com

\begin{abstract}
Abstrak
Penelitian ini merupakan Penelitian Tindakan Kelas (Classroom action Research) yang dilakukan untuk memecahkan masalah pembelajaran di kelas di masa pandemic Covid-19. Penelitian ini terdiri atas kajian teoritis yaitu kajian literatur dari suatu studi eksperimen yang berupaya menerapkan strategi pembelajaran berbasis Pembelajaran Aktif Inovatif Kreatif Efektif Menyenangkan (PAIKEM) di era pandemic Covid-19. Kegiatan pembelajaran dalam penelitian ini difokuskan pencatatan dana kas kecil yang dapat meningkatkan pemahaman dan keterampilan peserta didik kelas XI Perbankan dalam pengelolaan kas dengan menggunakan kolaborasi penerapan WhatsApp group dan Linoit. Dalam Penelitian Tindakan Kelas ini, peneliti melaksanakan pembelajaran, observasi dan hasil pembelajaran daring. Kemudian melaksanakan pembelajaran yang dirancang oleh peneliti sendiri dan bertanggung jawab penuh atas Penelitian Tindakan Kelas ini. Dari hasil penelitian yang dilaksanakan dalam masa pandemi Covid-19, penerapan media WhatsApp dan Linoit dapat meningkatkan hasil belajar siswa, Hal ini dapat dilihat dari nilai masing-masing individu. Rata-rata setiap siklus I adalah 64,95 dan meningkat menjadi 82,81 pada siklus II dan terdapat 19 siswa nilainya meningkat, 2 siswa dengan nilai tidak tuntas. Dari hasil tersebut diperoleh ketuntasan belajar $90,5 \%$.
\end{abstract}

Kata Kunci: whatshapp; linoit; hasil belajar

\section{Abstract}

This study is a Classroom action research conducted for classroom learning problems during the Covid-19 pandemic. This research consists of a study of the literature from the study that seeks to learn strategies to learn Creative Active Learning Fun Effective (PAIKEM) in the era of the Covid-19 pandemic. Otorah activities in this study fortitude of small cash funds that can be combined and the skills of students of class XI Banking in cash management by means of collaboration collaboration of WhatsApp and Linoit groups. In this Class Step Study, idiul researchers transported, observations and results of bold studies. Then do the yellowing conducted by researchers by researchers and responsible for the Research Results Of this Class. From the results of the study which during the Covid-19 pandemic, WhatsApp and Linoit application media can improve students' learning outcomes, this can be seen from the values of each individual. The average of each end is I 64.95 and increases to 82.81 at the end of II and there are 19 students whose grades increase, 2 students with incomplete grades. From the results, the completion of learning was $90.5 \%$.

$\begin{array}{ll}\text { How to cite: } & \text { Kartini, Sri (2021) Penerapan Media Whatsapp Group dan Linoit dalam Meningkatkan Hasil Belajar } \\ & \text { Pengelolaan Kas Kelas XI Perbankan SMK Negeri 1 Singkep Di Masa Pandemic Covid-19, Syntax } \\ & \text { Idea, 3(7). https://doi.org/10.36418/syntax-idea.v3i7.1316 } \\ \text { E-ISSN: } & \text { 2684-883X } \\ \text { Published by: } & \text { Ridwan Institute }\end{array}$


Sri Kartini

Keywords: whatshapp; linoit; learning outcomes

\section{Pendahuluan}

Pembelajaran secara daring atau online learning merupakan pembelajaran jarak jauh dengan menggunakan perangkat komputer atau gadget yang saling berhubungan di mana guru dan peserta didik berkomunikasi secara interaktif dengan memanfaatkan media komunikasi dan informasi. Pembelajaran ini sangat bergantung dengan koneksi jaringan internet yang menghubungkan antar perangkat guru dan para peserta didik. Pembelajaran daring ini sangat membantu dunia pendidikan kita di saat pandemi ini. Banyak aplikasi yang bisa dimanfaatkan dalam pembelajaran daring seperti Whatsapp Group, Google Classroom, Linoit, Edmodo, Quizzi, Zoom Cloud, Jitsi, dan lain-lain (Musfah, 2018).

Kendala di lapangan saat ini dalam melakukan pembelajaran online, antara lain: 1) Infrastruktur atau perangkat seperti komputer atau gadget. 2) Sebagian pendidik dan peserta didik masih belum memiliki dan terbiasa menggunakan dan mengoperasikan computer atau gadget terutama di daerah pedesaan. 3) Kurangnya jaringan signal yang kuat. 4) Kebiasaan cara belajar mengajar peserta didik dan guru yang sudah terbiasa belajar secara konvensional. 5) Guru masih belum terbiasa mengajar dengan memanfaatkan media daring kompleks yang harus dikemas dengan efektif, mudah diakses dan dipahami oleh peserta didik, sedangkan peserta didik sangat membutuhkan budaya belajar mandiri dan kebiasaan untuk belajar mengikuti pembelajaran memalui komputer atau gadget. 6) Masih rendahnya literasi peserta didik. 7) Tidak semua orang tua mempuanyai kemampuan untuk mendampingi anak baik dari segi waktu maupun pengetahuan. 8) Terjadinya miskonsepsi bawa pembelajatran jarak jauh hanya pembelajaran daring saja. 9) Banyak guru yang terlalu memaksakan sebuah aplikasi yang ditenggarai kekinian, namun tidak sesuai dengan tujuan awal dari sebuah pembelajaran daring, yang hasilnya bukan membantu meringankan beban psikis, namun malah membuat peserta didik menjadi stress ditambah lagi dengan banyaknya penugasan yang tidak terukur oleh gurunya (Purandina, 2020).

Sedangkan belajar di rumah ataupun belajar di sekolah, tetap harus berpihak pada siswa. Guru dan orang tua harus menciptakan pengalaman belajar yang melibatkan siswa. Diperlukan kolaborasi orang tua, guru dan siswa untuk berdaya belajar dalam menghadapi situasi darurat akibat wabah virus corona. Memastikan anak mendapatkan personalisasi pengalaman belajar yang bermakna, menantang dan sesuai dengan kemampuan dan kebutuhan anak. Praktik pembelajaran yang dilandasi orientasi pada anak berdasarkan relasi positif yang saling memahami antara guru murid dan orang tua (Badaruddin, 2015).

Untuk itu diperlukan pengumpulan informasi terlebih dahulu mengenai kesiapan orang tua dalam mendampingi peserta didik dalam melakukan pembelajaran jarak jauh. Faktor yang setidaknya perlu dipertimbangkan adalah akses orang tua terhadap teknologi, pola kerja orang tua dan tingkat pendidikan orang tua. Sediakan waktu berbincang dengan orang tua murid untuk mendapatkan gambaran kondisi yang mereka alami. Hal ini dilakukan agar dapat membangun kepercayaan diri murid dan orang tua, 
Penerapan Media Whatsapp Group dan Linoit dalam Meningkatkan Hasil Belajar

Pengelolaan Kas Kelas XI Perbankan SMK Negeri 1 Singkep Di Masa Pandemic

Covid-19

menghadirkan dukungan, pendorong semangat dan bantuan professional (Purba, Asnewastri, Hutauruk, Ginting, \& Resmi, 2021).

Dalam pembelajaran jarak jauh harus memperkirakan durasi pengerjaan tugas yang akan diberikan. Pastikan durasinya maksimal $80 \%$ dari belajar normal untuk menyediakan waktu belajar tidak terstruktur. Durasi ini bisa disesuaikan melalui koordinasi dengan guru yang mengajar pada kelas yang sama dan dengan murid / orangtua. Adanya kesepakatan dengan orang tua terkait cara pengerjaan tugas murid, jadwal dan durasi. Menyiapkan aktivitas dan tugas belajar yang memadukan tujuan kurikulum, minat dan isu hangat dibicarakan. Guru harus menghindari membuat aturan dan tugas yang tidak memahami kondisi murid dan orang tua. Hindari memaksakan tugas harus dikerjakan dengan kriteria dan durasi kecepatan yang sama untuk semua murid (Santoso, 2010).

Akhirnya guru dituntut untuk mampu merancang atau mendesain pembelajaran jarak jauh baik daring, luring maupun terpadu yang ringan dan efektif, dengan memanfaatkan perangkat atau media yang t.zepat dan sesuai dengan materi yang diajarkan. Guru harus mampu memilih dan membatasi sejauh mana cakupan materinya dan aplikasi apa yang cocok pada materi dan metode belajar yang digunakan untuk mempermudah peserta didik mendapat pembelajaran atau pendidikan dalam situasi pandemi covid-19 ini.

Dalam pembelajaran perbankan yang merupakan pelajaran yang membutuhkan ketelitihan, ketrampilan dan latihan yang berulang-ulang diperlukan pembelajaran jarak jauh daring, luring dan terpadu. Bagi peserta didik yang mempunyai fasilitas yang mendukung dan mereka menyukai menggunakan pembelajaran daring. Peserta didik yang tidak mempunyai fasilitas daring menggunakan pembelajaran luring. Dan untuk mengatasi kekurangan pembelajaran daring dan luring kita menggunakan pembelajaran terpadu (Naila, 2021).

Dengan kenyataan yang dihadapi diatas, guru mencoba berusaha bagaimana meningkatakan kembali hasil belajarnya seperti sebelum terjadi pandemic covid19 sehingga tidak menghambat ketuntasan dari kompetensi kejuruan yang telah diprogramkan. Peneliti mencoba menerapkan pembelajaran menggunakan media Whatsapp Group dan Linoit. Alasan menggunakan Whatsapp Group, karena pengoperasiannya sangat simple, mudah diakses, penggunaan paket internet yang murah dan waktu pengiriman tugas dan hasilnya bisa lebih fleksibel, serta bisa melakukan video call pada saat diskusi, sedangkan dengan aplikasi Linoit dengan penggunaan canvas yang berwarna warni akan membuat peserta didik lebih berminat untuk belajar dan materi diskusi daring bisa dibuka dimana saja sehingga dapat memotivasi peserta didiknya untuk tetap semangat dalam belajar secara online dan tidak menjadi beban psikis. Kedua aplikasi tersebut bisa dilakukan dengan kelompok kecil terutama yang rumahnya berdekatan dan anggotanya ada yang tidak punya HP. 
Judul yang diambil dalam penelitian ini adalah adalah "Penerapan media WhatsApp Group Dan Linoit Dalam Meningkatkan Hasil Belajar Pengelolaan Kas Kelas XI Perbankan SMK NEGERI 1 Singkep Di Masa Pandemic covid19”.

Hal ini sesuai dengan penelitian yang relevan yang dilakukan oleh Risha rafika, yang berjudul: Penerapan Model Cooperative Learning Menggunakan Whatsapp Group Pada Pembelajaran Jarak Jauh (Pjj) Di Masa Pandemi Covid-19. Melalui Penerapan metode ini menunjukkan dapat meningkatkan minat dan hasil belajar.

Berdasarkan dari uraian latar belakang diatas, rumusan masalah dalam penelitian ini adalah: Apakah penerapan media WhatsApp group dan linoit dapat meningkatkan hasil belajar pengelolaan kas kelas XI perbankan SMK Negeri 1 Singkep di masa pandemic covid19? Tujuan yang ingin dicapai dalam penelitian ini adalah : Untuk mengetahui peningkatan hasil belajar pengelolaan kas kelas XI perbankan SMK Negeri 1 Singkep di masa pandemic covid19 melalui penerapan media whatsapp group dan linoit.

\section{Metode Penelitian}

Penelitian Tindakan Kelas dilaksanakan di SMK Negeri 1 Singkep Jalan Gergas Batu Berdaun. Pelaksanaan dimulai September 2020 sampai dengan November 2020. Pelaksanaan ini dimaksudkan mulai dari mengidentifikasi masalah, merencanakan pembelajaran, melaksanakan tindakan, mengobservasi dan melakukan refleksi dari siklus I dan siklus II sampai dengan pelaporan. Subyek dari penelitian ini adalah peserta didik kelas XI Perbankan SMK Negeri 1 Singkep, yang terdiri dari 21 peserta didik semester ganjil tahun pelajaran 2020 / 2021.

Penelitian ini merupakan Penelitian Tindakan Kelas (Classroom action Research) yang dilakukan untuk memecahkan masalah pembelajaran di kelas. Penelitian ini terdiri atas kajian teoritis yaitu kajian literatur dari suatu studi eksperimen yang berupaya menerapkan strategi pembelajaran berbasis Pembelajaran Aktif Inovatif Kreatif Efektif Menyenangkan (PAIKEM) di masa pandemic Covid-19. Langkah-langkah penelitian Sebelum Pelaksanaan Penelitian Tindakan Kelas (Pra PTK) (Miaz, 2014).

1) Refleksi Awal.

Berdasarkan refleksi dari angket dan pre test, maka dapat disimpulkan bahwa hasil pembelajaran Pengelolaan Kas selama ini kurang memuaskan. Karena nilai peserta didik banyak di bawah kriteria ketuntasan minimal, pembelajaran yang dilakukan selama ini yaitu melalui daring dan tatap muka dengan waktu yang relaif singkat dikarenakan masih dalam kondisi pandemic covid19 .

2) Observasi untuk Mengidentifikasi Permasalahan di Kelas

Kegiatan ini dilaksanakan melalui analisis kegiatan pembelajaran di masa pandemic covid19 covid 19 pada peserta didik kelas XI Perbankan Semester Ganjil SMK Negeri 1 Singkep tahun pelajaran 2020/2021 sebelum dilaksanakan PTK, yang berisi hal-hal berkaitan dengan menurunnya hasil belajar peserta didik. Pelitian ini dilaksanakan dalam dua siklus. Persiapan dimulai pada bulan pertengahan Agustus, pelaksanaan pada bulan September, Oktober, November dan laporan dimulai bulan pertengahan Nopember. Hasil refleksi siklus I digunakan sebagai acuan dalam 
Penerapan Media Whatsapp Group dan Linoit dalam Meningkatkan Hasil Belajar

Pengelolaan Kas Kelas XI Perbankan SMK Negeri 1 Singkep Di Masa Pandemic

Covid-19

menentukan perbaikan tindakan pada siklus II. Sedangkan hasil refleksi siklus I nantinya digunakan sebagai acuan untuk rencana tindak lanjut pada pembelajaran selanjutnya.

Rincian Prosedur PTK: Adapun desain penelitian tindakan kelas yang akan dilaksanakan Penelitian Tindakan diadaptasi dari (Wardhani \& Muid, 2017)

Pada tahp ini hal-hal yang dilaksanakan peneliti adalah menyusun rencana pembelajaran sesuai dengan strategi pembelajaran observasi dengan kegiatan meliputi langkah-langkah sebagai berikut:

a) Menyusun rencana kegiatan pembelajaran untuk setiap pertemuan yang didalamnya memuat skenario pembelajaran sesuai dengan strategi yang dipilih

b) Menyusun instrumen pengumpul data yang berbentuk tugas

c) Menyusun lembar observasi untuk peserta didik yang digunakan dalam kegiatan pembelajaran selama PTK berlangsung, disertai dengan pedoman observasi.

d) Menyusun lembar observasi kinerja guru untuk setiap pertemuan. Lembar observasi ini digunakan sebagai pedoman penilaian oleh observer tehadap aktifitas peserta didik dalam pembelajaran

e) Mengisi jurnal kegiatan pembelajaran berupa catatan tentang berbagai hal yang muncul saat tindakan pembelajaran berlangsung bagi aktivitas peserta didik maupun aktivitas guru.

f) Menyusun data data hasil belajar sebelum pelaksanaan tindakan siklus I dan postes dilaksanakan setelah pelaksanaan tindakan siklus I.

3) Tahap Pelaksanaan Tindakan

Pelaksanaan tindakan disesuaikan dengan Rencana pelaksanaan pembelajaran.

Instrumen penelitian yang digunakan dalam PTK ini adalah: Soal pretes dan postes untuk mengetahui peningkatan hasil belajar peserta didik. Analisis data peneliti lakukan secara deskriptif kualitatif berdasarkan hasil observasi terhadap proses dan hasil belajar peserta didik, pengakuan peserta didik dalam pembelajaran dan studi dokumentasi hasil kerja peserta didik. Selanjutnya menetapkan pedoman peningkatan hasil belajar kelas XI Perbankan Semester Ganjil SMK Negeri 1 Singkep tahun pelajaran 2020/2021 dengan indikator sebagai berikut: Hasil belajar meningkat jika skor postes siklus I meningkat dari pretes dan skor postes siklus II meningkat dari postes siklus I, dengan standar ketuntasan belajar secara individu sebesar $\geq 75$.

\section{Hasil dan Pembahasan}

\section{A. Hasil Penelitian}

\section{Hasil Penelitian dan Pembahasan Siklus 2}

a. Hasil Penelitian Siklus 2

Hasil belajar dari tindakan siklus II diperoleh data sebagaimana terdapat pada tabel berikut: 
Tabel 1

Data Nilai Evaluasi Pengelolaan Kas Kelas XI PKM Siklus II

\begin{tabular}{|c|c|c|c|c|}
\hline No & Nama peserta didik & Jenis Kelamin & $\begin{array}{c}\text { Nilai } \\
\text { Siklus II }\end{array}$ & Keterangan \\
\hline 1 & ADINDA JULIA ZAHRA & $\mathrm{P}$ & 100 & Tuntas \\
\hline 2 & ANANDA NEW ZEFIT & $\mathrm{L}$ & 60 & Tidak Tuntas \\
\hline 3 & DINI PUTRI HERNI & $\mathrm{P}$ & 75 & Tidak Tuntas \\
\hline 4 & ELVI & $\mathrm{P}$ & 100 & Tuntas \\
\hline 5 & FIRANDA & $\mathrm{P}$ & 75 & Tuntas \\
\hline 6 & HUDILA & $\mathrm{P}$ & 100 & Tuntas \\
\hline 7 & MEGA JULIANTI & $\mathrm{P}$ & 90 & Tuntas \\
\hline 8 & MIRA AGUSTIN & $\mathrm{P}$ & 75 & Tuntas \\
\hline 9 & M INDRA WAHYUDI & $\mathrm{L}$ & 92 & Tuntas \\
\hline 10 & NADIA & $\mathrm{P}$ & 79 & Tuntas \\
\hline 11 & NOVITA NURUL AULIA & $\mathrm{P}$ & 40 & Tidak Tuntas \\
\hline 12 & NOPI AFRIA & $\mathrm{P}$ & 90 & Tuntas \\
\hline 13 & NOVI SAPUTRA & $\mathrm{L}$ & 96 & Tuntas \\
\hline 14 & PAHARI AGUSTIAN & $\mathrm{L}$ & 80 & Tuntas \\
\hline 15 & RAHMADA FITRI YANI & $\mathrm{P}$ & 80 & Tuntas \\
\hline 16 & RANI INDRIYANTI & $\mathrm{P}$ & 90 & Tuntas \\
\hline 17 & RENATA & $\mathrm{L}$ & 80 & Tuntas \\
\hline 18 & SINTA BELA & $\mathrm{P}$ & 75 & Tuntas \\
\hline 19 & TASYA DARASISTA & $\mathrm{P}$ & 87 & Tuntas \\
\hline 20 & WILLY YANI PUTRI & $\mathrm{P}$ & 90 & Tuntas \\
\hline \multirow[t]{3}{*}{21} & ZAKIA AZZAHARA & $\mathrm{P}$ & 75 & tuntas \\
\hline & Tuntas $: 19=90,5 \%$ & & $1739=82,81$ & \\
\hline & $\begin{array}{lc}\text { Tidak Tuntas } & : 2=9,5 \% \\
\text { Nilai Tertingi } & ; 100 \\
\text { Nilai Terendah } & : 40\end{array}$ & & & \\
\hline
\end{tabular}

Setelah dilakukan analisis data hasil tes siklus 2 dengan metode pencatatan dana kas kecil, diperoleh nilai rata-rata peserta didik sebesar 82,81. Peserta didik yang tuntas sebanyak 19 anak $(90,5 \%)$, peserta didik yang tidak tuntas sebanyak 2 anak (9,5\%) dengan nilai tertinggi 100 dan nilai terendah. Siklus 2 merupakan pembelajaran dengan materi laporan mutasi kas kecil yang dilaksanakan dalam dua kali pertemuan. Hasil penelitian siklus 2 terdapat peningkatan. Hal ini dapat terlihat dari tabel 4.3 diperoleh rata-rata hasil tes yang diberikan kepada peserta didik pada siklus 2 adalah sebesar 82,81. Ketuntasan belajar secara klasikal sebesar 90,5\% atau sebanyak 19 peserta didik memperoleh nilai $\geq 75$. Dengan demikian hasil belajar pada siklus 2 ini sudah sesuai dengan indikator keberhasilan yang ditetapkan, sehingga tidak perlu dilakukan siklus selanjutnya (Marina, Wahjono, \& Suarni, 2018).

Kenaikan hasil belajar pada siklus 2 tidak lepas dari adanya peningkatan aktivitas peserta didik dibandingkan dengan siklus 1 . Hal ini 
Penerapan Media Whatsapp Group dan Linoit dalam Meningkatkan Hasil Belajar Pengelolaan Kas Kelas XI Perbankan SMK Negeri 1 Singkep Di Masa Pandemic

Covid-19

menunjukkan peserta didik dalam melakukan aktivitas yang diharapkan lebih banyak dibandingkan dengan siklius 1 . Ini berarti peserta didik lebih terarah pada kerjasama kelompok, meningkatnya diskusi dan tanya jawab dalam kelompok serta lebih berani dalam mengungkapkan pendapatnya, ditandai dengan adanya peserta didik yang bertanya serta menjawab pertanyaan. peserta didik juga telah bekerja sama dengan kelompoknya secara baik, walaupun dalam menggunakan alat peraga dan mengisi lembar kerja masih didominasi peserta didik yang rajin. Tetapi peserta didik yang rajin di sini sudah mulai menularkan idenya kepada peserta didik lain yang masih kurang, sehingga semua anggota kelompok memahami diskusi. Hal tersebut sesuai dengan pendapat (Lie, 2012) yang menyatakan bahwa pembagian kelompok secara heterogen memberikan kesempatan untuk saling mendukung, meningkatkan relasi dan interaksi serta memudahkan pengelolaan kelas, karena dengan adanya peserta didik yang berkemampuan akademis yang tinggi guru mendapatkan asisten untuk kelompok. Oleh karena itu belajar kelompok sangat diperlukan agar diperoleh hasil belajar yang lebih baik. Hal ini sudah sesuai dengan apa yang diharapkan dalam pembelajaran dengan menggunakan WhatsApp group dan linoit bahwa peserta didik menyatukan pendapatnya terhadap jawaban pertanyaan / tugas dari guru dan meyakinkan tiap anggota dalam timnya mengetahui jawaban itu.

Tabel 2

Perbandingan Hasil Belajar Siklus I dan Siklus II

\begin{tabular}{llccl}
\hline \multirow{2}{*}{ No } & \multicolumn{1}{c}{ Nama peserta didik } & $\begin{array}{c}\text { Nilai } \\
\text { Siklus I }\end{array}$ & $\begin{array}{c}\text { Nilai } \\
\text { Siklus II }\end{array}$ & \multicolumn{1}{c}{ Keterangan } \\
\hline 1 & ADINDA JULIA ZAHRA & 90 & 100 & Meningkat \\
\hline 2 & ANANDA NEW ZEFIT & 60 & 60 & Tetap \\
\hline 3 & DINI PUTRI HERNI & 65 & 75 & Meningkat \\
\hline 4 & ELVI & 90 & 100 & Meningkat \\
\hline 5 & FIRANDA & 60 & 75 & Meningkat \\
\hline 6 & HUDILA & 85 & 100 & Meningkat \\
\hline 7 & MEGA JULIANTI & 75 & 90 & Meningkat \\
\hline 8 & MIRA AGUSTIN & 60 & 75 & Meningkat \\
\hline 9 & M INDRA WAHYUDI & 80 & 92 & Meningkat \\
\hline 10 & NADIA & 75 & 79 & Meningkat \\
\hline 11 & NOVITA NURUL AULIA & 40 & 40 & Tetap \\
\hline 12 & NOPI AFRIA & 65 & 90 & Meningkat \\
\hline 13 & NOVI SAPUTRA & 85 & 96 & Meningkat \\
\hline 14 & PAHARI AGUSTIAN & 60 & 80 & Meningkat \\
\hline 15 & RAHMADA FITRI YANI & 65 & 80 & Meningkat \\
\hline 16 & RANI INDRIYANTI & 80 & 90 & Meningkat \\
\hline 17 & RENATA & 80 & 80 & Tetap \\
\hline 18 & SINTA BELA & 40 & 75 & Meningkat \\
\hline 19 & TASYA DARASISTA & 75 & 87 & Meningkat \\
\hline 20 & WILLY YANI PUTRI & 60 & 90 & Meningkat \\
\hline
\end{tabular}




\begin{tabular}{lcccc}
\hline \multirow{2}{*}{ No } & Nama peserta didik & Nilai & Nilai & Keterangan \\
\hline 21 & ZAKIA AZZAHARA & 50 & 75 & Meningkat \\
\hline & & $1363=64,95$ & $1739=82,81$ & \\
\hline
\end{tabular}

Dari tabel 2, bahwa dengan kolaborasi Penerapan media WhatsApp dan Linoit hasil belajar yang didapat oleh siswa ada peningkatan nilai yang cukup besar. Itu bisa dilihat dari nilai masing-masing individu yang terdapat pada tabel di atas. Bukan itu saja nilai rata-rata setiap siklus I sampai II juga mengalami peningkatan dalam pembelajaran yaitu rata-rata 64,95 pada siklus I dan meningkat menjadi 82,81 pada siklus 2. Hal ini sesuai dengan pendapat Trisnani, bahwa media WhatsApp (WA) telah dimanfaatkan oleh siswa untuk berkomunikasi dalam menyampaikan pesan kepada sasarannya. guru memanfaatkan WA sebagai media komunikasi dalam menyampaikan pesan, informasi yang disampaikan lebih efektif dan merupakan kepuasan tersendiri karena menggunakan teknologi informasi (WA) pesan lebih cepat diterima oleh sasaran siswa. Selain itu sesuai juga apa yang dikatakan (Jumiatmoko, 2016), bahwa WhatsApp merupakan aplikasi berbasis internet yang memungkinkan setiap penggunanya dapat saling berbagi berbagai macam konten sesuai dengan fitur pendukungnya. WhatsApp juga memiliki berbagai fitur yang dapat digunakan untuk berkomunikasi dengan bantuan layanan internet.

\section{B. Pembahasan}

\section{Paparan Data Pra Tindakan}

Sebelum penelitian dilaksanakan, peneliti mengadakan pembelajaran daring yang dimulai pada pertengahan Maret 2020 sampai Juni 2020 karena adanya covid 19. Pada saat memasuki tahun ajaran baru ternyata pandemic covid 19 covid 19 belum juga berlalu, pemerintah menganjurkan tetap melakukan pembelajaran dari rumah. Sehingga awal tahun ajaran baru pertengahan bulan Juli 2020 dilakukan pembelajaran kombinasi daring dan luring jadi pilihan, namun hasilnya masih belum memuaskan karena masih banyak peserta didik yang tidak aktif dalam pembelajaran dan tidak mengumpulkan tugas dengan alasan sinyal, paket internet, tidak punya HP dan sebagainya (Adawiyah \& Kadir, 2020).

Dengan alasan di atas, bulan Agustus peneliti mulai merencanakan melakukan penelitian Tindakan dengan konsultasi dengan rekan kerja sekaligus waka kurikulum yang ternyata juga menghadapi hal yang sama dalam pembelajarannya. Peserta didik yang bermasalah dalam pembelajaran ternyata punya kesamaan dan dengan alasan yang sama. Kemudian peneliti mengadakan pertemuan dengan Kepala Sekolah, Wakil Kepala Sekolah bagian kurikulum dan bermaksud untuk mengadakan penelitian di SMK Negeri 1 Singkep. Kepala Sekolah menyambut baik keinginan peneliti dan memberikan izin untuk melaksanakan penelitian. Selanjutnya Kepala Sekolah menyerahkan sepenuhnya kepada Waka Kurikulum untuk merencanakan rencana selanjutnya. 
Penerapan Media Whatsapp Group dan Linoit dalam Meningkatkan Hasil Belajar Pengelolaan Kas Kelas XI Perbankan SMK Negeri 1 Singkep Di Masa Pandemic

Covid-19

Peneliti mencari tahu keadaan peserta didik yang sebenarnya selama pembelajaran daring, hasil yang diperoleh adalah selama pembelajaran daring peserta didik kurang berminat membaca materi yang dikirim oleh guru karena dia lebih tertarik membuka HP itu untuk bermain game dan media social dan orang tua hanya tahu mereka memakai HP untuk belajar karena mereka tidak mengerti, peserta didik merasa tidak ada beban dalam belajar karena tidak langsung dipantau guru, tidak semua orang tua mau memantau peserta didiknya untuk belajar. Berikut Nilai Peserta Didik Pada Saat Pembelajaran Daring Bulan Juli.

Tabel 3

Nilai Peserta Didik Pada Saat Pembelajaran Daring Bulan Juli

\begin{tabular}{ccccc}
\hline No & Nama Peserta Didik & $\begin{array}{c}\text { Jenis } \\
\text { Kelamin }\end{array}$ & $\begin{array}{c}\text { Nilai } \\
\text { Pra Siklus }\end{array}$ & Keterangan \\
\hline 1 & Adinda Julia Zahra & $\mathrm{P}$ & 80 & Tuntas \\
\hline 2 & Ananda New Zefit & $\mathrm{L}$ & 20 & Tidak Tuntas \\
\hline 3 & Dini Putri Herni & $\mathrm{P}$ & 45 & Tidak Tuntas \\
\hline 4 & Elvi & $\mathrm{P}$ & 80 & Tuntas \\
\hline 5 & Firanda & $\mathrm{P}$ & 40 & Tidak Tuntas \\
\hline 6 & Hudila & $\mathrm{P}$ & 75 & Tuntas \\
\hline 7 & Mega Julianti & $\mathrm{P}$ & 65 & Tidak Tuntas \\
\hline 8 & Mira Agustin & $\mathrm{P}$ & 60 & Tidak Tuntas \\
\hline 9 & M Indra Wahyudi & $\mathrm{L}$ & 70 & Tidak Tuntas \\
\hline 10 & Nadia & $\mathrm{P}$ & 70 & Tidak Tuntas \\
\hline 11 & Novita Nurul Aulia & $\mathrm{P}$ & 40 & Tidak Tuntas \\
\hline 12 & Nopi Afria & $\mathrm{P}$ & 65 & Tidak Tuntas \\
\hline 13 & Novi Saputra & $\mathrm{L}$ & 80 & Tuntas \\
\hline 14 & Pahari Agustian & $\mathrm{L}$ & 60 & Tidak Tuntas \\
\hline 15 & Rahmada Fitri Yani & $\mathrm{P}$ & 65 & Tidak Tuntas \\
\hline 16 & Rani Indriyanti & $\mathrm{P}$ & 80 & Tuntas \\
\hline 17 & Renata & $\mathrm{L}$ & 80 & Tuntas \\
\hline 18 & Sinta Bela & $\mathrm{P}$ & 40 & Tidak Tuntas \\
\hline 19 & Tasya Darasista & $\mathrm{P}$ & 45 & Tidak Tuntas \\
\hline 20 & Willy Yani Putri & $\mathrm{P}$ & 40 & Tidak Tuntas \\
\hline 21 & Zakia Azzahara & $\mathrm{P}$ & 30 & Tidak Tuntas \\
\hline & & & $1230=58,57$ & \\
\hline & & & & \\
\hline & & & & \\
\hline
\end{tabular}

\section{Penelitian Siklus I}

\section{Tabel 4}

Tahapan Pelaksanaan Penelitian Siklus I

\begin{tabular}{llll}
\hline $\begin{array}{c}\text { Tahapan } \\
\text { PTK }\end{array}$ & \multicolumn{1}{c}{ Prosedur Penelitian } & \multicolumn{2}{c}{ Keterangan } \\
\hline Pra penelitian & $\bullet$ & Wawancara dengan guru mata pelajaran & Dengan Bu \\
& $\begin{array}{l}\text { produktif untuk mengetahui gambaran } \\
\text { mengenai permasalahan pembelajaran }\end{array}$ & $\begin{array}{l}\text { Triwahyuni, } \\
\text { produksif perbankan } \\
\text { pada mata pelajaran selain Pengelolaan } \\
\text { Kas }\end{array}$ & \\
& & & \\
\hline
\end{tabular}




\begin{tabular}{|c|c|c|}
\hline $\begin{array}{l}\text { Tahapan } \\
\text { PTK }\end{array}$ & Prosedur Penelitian & Keterangan \\
\hline & $\begin{array}{l}\text { - Melakukan observasi dan analisis hasil } \\
\text { belajar peserta didik. } \\
\text { Mengidentifikasi permasalahan yang } \\
\text { terkait dengan pembelajaran di sekolah, } \\
\text { merumuskan dan menentukan metode } \\
\text { penelitian, sampel penelitian, serta } \\
\text { kompetensi dasar yang dijadikan materi. } \\
\text { Berkonsultasi dengan guru mata pelajaran } \\
\text { produktif perbankan terkait dengan } \\
\text { pelaksanaan proses pembelajaran dengan } \\
\text { menerapkan Kolaborasi WhatsApp group } \\
\text { group dan Linoit }\end{array}$ & $\begin{array}{lr}\text { Masalah: } & \text { perserta didik } \\
\text { kurang } & \text { merespon } \\
\text { terhadap pelajaran daring, } \\
\text { tidak } \\
\text { tugas }\end{array}$ \\
\hline $\begin{array}{l}\text { Perencanaan } \\
\text { (Planning) }\end{array}$ & 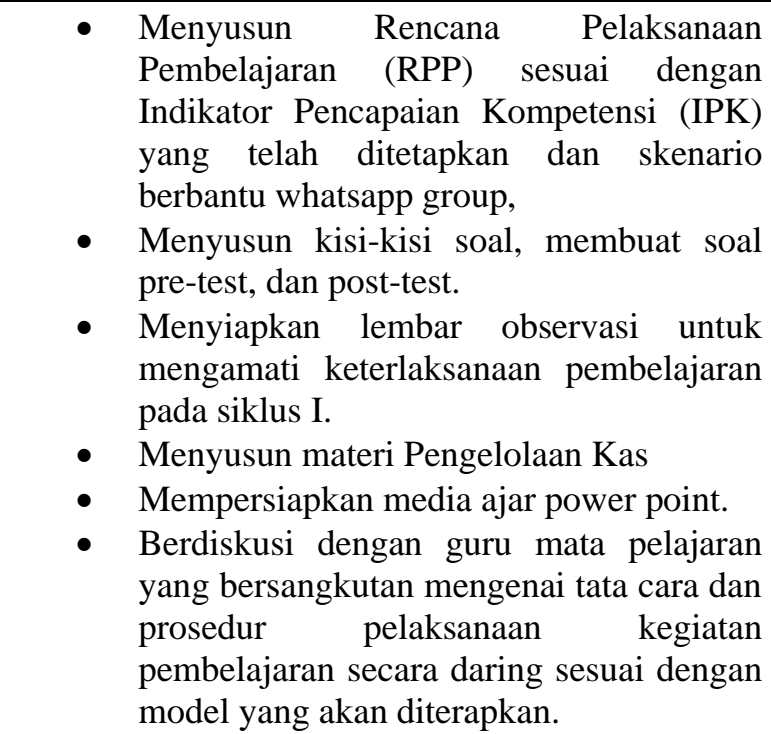 & $\begin{array}{lr}\text { Pembelajaran } & \text { dengan } \\
\text { tatap muka } & \text { (waktu } \\
\text { singkat) dan daring (masa } \\
\text { pandemic } \\
\text { covid19 }\end{array}$ \\
\hline $\begin{array}{l}\text { Pra-Tindakan } \\
\text { (Pre-Action) - }\end{array}$ & $\begin{array}{l}\text { - Memberikan pengumuman melalui grup } \\
\text { terkait waktu pelaksanaan pembelajaran } \\
\text { secara daring akan dimulai. } \\
\text { Mempersiapkan alat dan bahan ajar yang } \\
\text { digunakan meliputi laptop, materi ajar } \\
\text { (power point), whatsapp yang terkoneksi } \\
\text { dengan internet, presensi peserta didik, } \\
\text { soal pre-test dan post-test, dan lembar } \\
\text { observasi keterlaksanaan model } \\
\text { pembelajaran. } \\
\text { kegiatan pembelajaran, mengintruksikan } \\
\text { peserta didik mengisi soal pre-test terlebih } \\
\text { dahulu. } \\
\text { Menerapkan model pembelajaran } \\
\text { berbantu whatsapp dan linoit group pada } \\
\text { mata pelajaran Pengelolaan Kas. } \\
\text { Materi yang digunakan yaitu metode } \\
\text { pengelolaan kas kecil }\end{array}$ & \\
\hline $\begin{array}{l}\text { Tindakan } \\
\text { (Action) } \\
\text { Orientasi }\end{array}$ & $\begin{array}{l}\text { Apersepsi, motivasi, penyampaian tujuan } \\
\text { - Guru memberi salam dan menyapa peserta } \\
\text { - } \text { didik. } \\
\text { - Guru menanyakan kondisi peserta didik. }\end{array}$ & \begin{tabular}{llr} 
- & \multicolumn{2}{l}{ Pembelajaran } \\
tatap & muka \\
(waktu & relative \\
singkat) & untuk \\
\end{tabular} \\
\hline
\end{tabular}




\begin{tabular}{|c|c|c|}
\hline $\begin{array}{c}\text { Tahapan } \\
\text { PTK }\end{array}$ & Prosedur Penelitian & Keterangan \\
\hline & $\begin{array}{l}\text { - Guru membuka pelajaran dengan } \\
\text { melakukan doa bersama yang dipimpin } \\
\text { oleh salah seorang peserta didik. } \\
\text { - Guru mengecek kehadiran peserta didik. } \\
\text { - Guru mengecek dan menginstruksikan } \\
\text { kembali peserta didik yang belum mengisi } \\
\text { soal pre-test. } \\
\text { - Guru memberikan motivasi belajar kepada } \\
\text { peserta didik. } \\
\text { - Guru menyampaikan manfaat materi } \\
\text { pembelajaran pengelolaan kas dalam } \\
\text { kehidupan sehari-hari } \\
\text { Guru menyampaikan kompetensi, lingkup } \\
\text { materi dan tujuan pembelajaran yang akan } \\
\text { dicapai peserta didik. }\end{array}$ & $\begin{array}{l}\text { membahas yang } \\
\text { tidak bisa } \\
\text { dijelaskan di wa } \\
\text { group } \\
\text { - Pembelajaran } \\
\text { daring. } \\
\text { Materi dan tugas } \\
\text { ada dalam bentuk } \\
\text { power point } \\
\text { dikirim lewat } \\
\text { WhatsApp group } \\
\text { group } \\
\text { Diskusi melalui } \\
\text { wa group }\end{array}$ \\
\hline & $\begin{array}{l}\text { Menyajikan informasi } \\
\text { - Guru memperlihatkan contoh metode } \\
\text { pengelolaan dana kas kecil } \\
\text { - Guru memberikan pertanyaan mendasar } \\
\text { mengenai topik yang sesuai dengan realita } \\
\text { dunia nyata kepada peserta didik. } \\
\text { - Apakah peserta didik pernah memikirkan } \\
\text { Bagaimana perusahaan melakukan } \\
\text { pencatatan kas• } \\
\text { Mengapa perlu dilakukan pencatatan yang } \\
\text { tepat? } \\
\text { Guru mengintruksikan peserta didik untuk } \\
\text { mencari informasi dari berbagai sumber } \\
\text { dibimbing. } \\
\text { Guru memberikan materi metode } \\
\text { pengelolaan dana kas kecil } \\
\text { Guru memberikan kesempatan peserta } \\
\text { didik untuk bertanya jika belum } \\
\text { memahami materi yang disampaikan. (30 } \\
\text { menit) }\end{array}$ & \\
\hline & $\begin{array}{l}\text { Mengorganisasikan peserta didik } \\
\text { - Guru membagi peserta didik menjadi } 4 \\
\text { - Gang terdiri dari } 4 \text { atau } 5 \text { anggota. } \\
\text { Guru menjelaskan petunjuk kegiatan } \\
\text { setiap kelompok } \\
\text { Guru menginstruksikan peserta didik } \\
\text { untuk mengingat siapa teman dalam satu } \\
\text { kelompoknya,. } \\
\text { - Guru mengirimkan materi dan lembar } \\
\text { kerja melalui whatsapp group. } \\
\text { - Guru memberikan batas waktu yang } \\
\text { ditentukan. }\end{array}$ & $\begin{array}{l}\text { WA Group/kelompok } \\
\text { yang dibuat anggotanya } \\
\text { lebih sedikit dari } \\
\text { sebelumnya. } \\
\text { WhatsApp group group } \\
\text { untuk share materi dan } \\
\text { diskusi } \\
\text { Linoit digunakan untuk } \\
\text { share jawaban yang benar } \\
\text { agar tersimpan dan bisa } \\
\text { dibuka kapanpun. } \\
\text { Guru selalu menanyakan }\end{array}$ \\
\hline
\end{tabular}




\begin{tabular}{|c|c|c|}
\hline $\begin{array}{c}\text { Tahapan } \\
\text { PTK }\end{array}$ & Prosedur Penelitian & Keterangan \\
\hline & 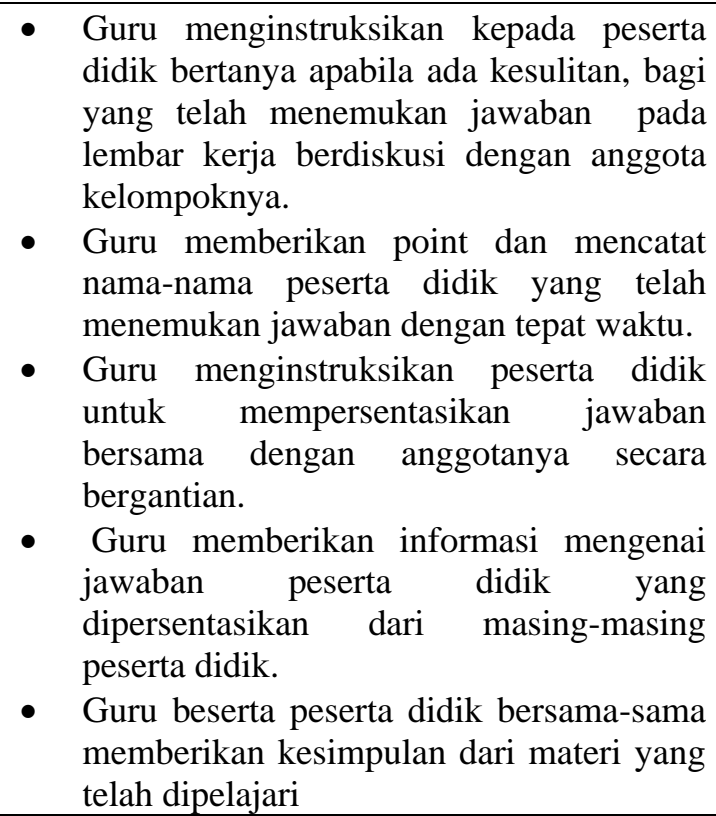 & $\begin{array}{l}\text { anggota group yang } \\
\text { belum aktif komentar, } \\
\text { bertanya, atau belum } \\
\text { mengumpulkan tugas. } \\
\text { Presentasi bisa melalui } \\
\text { WA group, linoit atau } \\
\text { langsung saat tatap muka }\end{array}$ \\
\hline & $\begin{array}{l}\text { valuasi } \\
\text { - Guru memberikan evaluasi berupa post- } \\
\text { test untuk mengukur ketercapaian } \\
\text { pembelajaran. } \\
\text { - Guru menyampaikan rencana } \\
\text { pembelajaran pada pertemuan berikutnya. } \\
\text { - Guru mengakhiri kegiatan belajar dengan } \\
\text { memberikan pesan semangat dan motivasi } \\
\text { belajar. } \\
\text { Guru meminta salah satu peserta didik } \\
\text { untuk memimpin doa. } \\
\text { Guru akhiri pembelajaran dan } \\
\text { mengucapkan salam. }\end{array}$ & \\
\hline $\begin{array}{l}\text { Pengamatan } \\
\text { (Observation) }\end{array}$ & $\begin{array}{l}\text { - Pada tahap ini dilakukan } \\
\text { bersamaan pada waktu } \\
\text { pembelajaran berlangsung. } \\
\text { - } \\
\text { Pelaksanaan observasi dilakukan oleh } \\
\text { peneliti dibantu observer I dengan } \\
\text { menggunakan lembar observasi untuk } \\
\text { mengetahui aktivitas guru dan peserta } \\
\text { didik selama proses pembelajaran }\end{array}$ & \\
\hline $\begin{array}{l}\text { Refleksi } \\
\text { (Reflexy) }\end{array}$ & $\begin{array}{l}\text { - Hasil refleksi digunakan untuk } \\
\text { menetapkan langkah selanjutnya dalam } \\
\text { upaya untuk menghasilkan perbaikan pada } \\
\text { siklus selanjutnya. Data hasil observasi } \\
\text { dan hasil belajar peserta didik (pre-test } \\
\text { dan post-test) kemudian dianalisis sebagai } \\
\text { data kajian untuk melakukan refleksi, } \\
\text { sehingga dapat diketahui perkembangan } \\
\text { yang diperoleh dari kolaborasi penerapan } \\
\text { WhatsApp group dan linoit }\end{array}$ & \\
\hline
\end{tabular}


Penerapan Media Whatsapp Group dan Linoit dalam Meningkatkan Hasil Belajar Pengelolaan Kas Kelas XI Perbankan SMK Negeri 1 Singkep Di Masa Pandemic

Dari pelaksanaan siklus 1, diperoleh berbagai data yaitu data hasil belajar peserta didik dan data hasil observasi aktivitas peserta didik terhadap pembelajaran.

\section{Hasil Belajar Peserta didik}

Hasil belajar dari tindakan siklus 1 diperoleh data sebagaimana terdapat pada tabel berikut:

Tabel 5

Tabel Data Nilai Evaluasi Pengelolaan Kas Kelas XI PKM SMK Negeri 1 Singkep Siklus Pertama

\begin{tabular}{|c|c|c|c|c|}
\hline No & Nama peserta didik & $\begin{array}{c}\text { Jenis } \\
\text { Kelamin }\end{array}$ & $\begin{array}{c}\text { Nilai } \\
\text { Siklus I }\end{array}$ & Keterangan \\
\hline 1 & ADINDA JULIA ZAHRA & $\mathrm{P}$ & 90 & Tuntas \\
\hline 2 & ANANDA NEW ZEFIT & $\mathrm{L}$ & 60 & Tidak Tuntas \\
\hline 3 & DINI PUTRI HERNI & $\mathrm{P}$ & 65 & Tidak Tuntas \\
\hline 4 & ELVI & $\mathrm{P}$ & 90 & Tuntas \\
\hline 5 & FIRANDA & $\mathrm{P}$ & 60 & Tidak Tuntas \\
\hline 6 & HUDILA & $\mathrm{P}$ & 85 & Tuntas \\
\hline 7 & MEGA JULIANTI & $\mathrm{P}$ & 75 & Tuntas \\
\hline 8 & MIRA AGUSTIN & $\mathrm{P}$ & 60 & Tidak Tuntas \\
\hline 9 & M INDRA WAHYUDI & $\mathrm{L}$ & 80 & Tuntas \\
\hline 10 & NADIA & $\mathrm{P}$ & 75 & Tuntas \\
\hline 11 & NOVITA NURUL AULIA & $\mathrm{P}$ & 40 & Tidak Tuntas \\
\hline 12 & NOPI AFRIA & $\mathrm{P}$ & 65 & Tidak Tuntas \\
\hline 13 & NOVI SAPUTRA & $\mathrm{L}$ & 85 & Tuntas \\
\hline 14 & PAHARI AGUSTIAN & $\mathrm{L}$ & 60 & Tidak Tuntas \\
\hline 15 & RAHMADA FITRI YANI & $\mathrm{P}$ & 65 & Tidak Tuntas \\
\hline 16 & RANI INDRIYANTI & $\mathrm{P}$ & 80 & Tuntas \\
\hline 17 & RENATA & $\mathrm{L}$ & 80 & Tuntas \\
\hline 18 & SINTA BELA & $\mathrm{P}$ & 40 & Tidak Tuntas \\
\hline 19 & TASYA DARASISTA & $\mathrm{P}$ & 75 & Tuntas \\
\hline 20 & WILLY YANI PUTRI & $\mathrm{P}$ & 60 & Tidak Tuntas \\
\hline \multirow[t]{6}{*}{21} & \multirow[t]{2}{*}{ ZAKIA AZZAHARA } & $\mathrm{P}$ & 50 & Tidak tuntas \\
\hline & & & $363=64,95$ & \\
\hline & $: 10=48 \%$ & & & \\
\hline & Tidak Tuntas & & & \\
\hline & Nilai Tertingi & & & \\
\hline & Nilai Terendah & & & \\
\hline
\end{tabular}

Setelah dilakukan analisis data hasil tes siklus 1 dengan sub pokok bahasan pencatatan dana kas kecil diperoleh nilai rata-rata peserta didik sebesar 64,95, peserta didik yang tuntas sebanyak 10 anak (48\%), peserta didik yang tidak tuntas.

\section{Pembahasan dan Refleksi Siklus 1}

Siklus 1 merupakan pembelajaran dengan materi pencatatan buku dana kas kecil yang dilakukan dalam tiga kali pertemuan. Hasil penelitian pada siklus 1 dapat dijelaskan diperoleh data hasil belajar, dimana ketuntasan belajar klasikal sebesar $48 \%$ atau sebanyak 10 anak tuntas belajar dengan mendapatkan nilai $\geq$ 
75. Hal ini dikarenakan sudah adanya keterlibatan peserta didik selama proses pembelajaran terutama dalam mengaktifkan HP saat jam belajar, melakukan diskusi untuk mengerjakan tugas dengan kelompoknya, karena pembelajaran akan berkesan bila peserta didik terlibat langsung didalamnya (pembelajaran dilaksanakan dengan tatap muka dengan jam lebih pendek dari biasanya dan juga dilakukan daring melalui WhatsApp group group) (Kusumaningrum, 2012).

Pada siklus 1, dari setiap pertemuan maupun diskusi lewat WhatsApp group menunjukkan peningkatan aktifitas belajar peserta didik dibandingkan sebelum dilakukan siklus. Seperti meningkatnya antusias dan motivasi peserta didik dalam mengikuti pembelajaran, karena dorongan dan pemberian motivasi oleh guru. Untuk kerja kelompokpun menunjukkan aktivitas, seperti meningkatnya diskusi dan tanya jawab antar teman dalam kelompok, serta memberi pendapat tentang hasil yang dipresentasikan. Selain itu dalam mengkaji ulang/melakukan evaluasi dan membuat kesimpulan juga semakin meningkat meskipun masih kurangnya penguasaan materi peserta didik dengan pembelajaran kolaborasi penerapan WhatsApp group dan linoit. Karena masih banyak yang belum mendapatkan nilai tuntas atau masih ada peserta didik lain belum menunjukkan aktivitas yang optimal sesuai yang diharapkan sehingga perlu ditingkatkan (Kurniati \& Nuroso, 2020).

Kekurangan dalam pembelajaran tersebut perlu adanya perbaikan dengan memberikan dorongan motivasi kepada peserta didik untuk bersungguh-sungguh dalam mengerjakan tugas, menyatukan pendapat, tidak boleh mengganggu teman serta melakukan diskusi secara aktif dan memberi pujian bagi peserta didik yang bertanya dan menjawab pertanyaan. Guru harus mampu memberi perhatian serta motivasi terhadap kegiatan peserta didik dalam kelompoknya. Hal ini didukung pernyataan yang dikemukakan oleh Hamalik tahun 2011, bahwa motivasi menentukan tingkat keberhasilan dan kegagalan dalam belajar Permasalahan ini akan diupayakan perbaikan pada siklus 2 dengan memotivasi pada peserta didik untuk lebih aktif dalam pembelajaran.

\section{Penelitian Siklus II}

\section{Tabel 6}

Tahapan Prosedur Penelitian Siklus II

\begin{tabular}{lll}
\hline $\begin{array}{c}\text { Tahapan } \\
\text { Penelitian }\end{array}$ & & Keterangan \\
\hline $\begin{array}{l}\text { Perencanaan } \\
\text { (Planning) }\end{array}$ & 1. $\begin{array}{l}\text { Mendata masalah dan kendala yang dihadapi } \\
\text { selama proses pembelajaran daring yang } \\
\text { telah dilaksanakan pada siklus I. }\end{array}$ \\
2. $\begin{array}{l}\text { Merancang perbaikan untuk proses } \\
\text { pembelajaran daring pada siklus II } \\
\text { berdasarkan refleksi pada siklus I. }\end{array}$ \\
3. $\begin{array}{l}\text { Membuat Rancangan Pelaksanaan } \\
\text { Pembelajaran (RPP) yang telah disesuaikan } \\
\text { 4enyiapkan perangkat pembelajaran yang } \\
\text { akan digunakan selama proses pembelajaran } \\
\text { Kolaborasi penerapan WhatsApp group } \\
\text { group dan Linoit }\end{array}$ \\
\hline
\end{tabular}




\begin{tabular}{|c|c|c|}
\hline $\begin{array}{l}\text { Tahapan } \\
\text { Penelitian }\end{array}$ & & Keterangan \\
\hline & $\begin{array}{l}\text { 5. Menyiapkan lembar observasi untuk } \\
\text { mengamati proses pembelajaran pada siklus } \\
\text { II. }\end{array}$ & \\
\hline $\begin{array}{l}\text { Pra-Tindakan } \\
\text { (Pre-Action) }\end{array}$ & $\begin{array}{l}\text { 1. Memberikan pengumuman melalui grup } \\
\text { terkait waktu pelaksanaan pembelajaran } \\
\text { secara daring akan dimulai. } \\
\text { 2. Mempersiapkan alat dan bahan ajar yang } \\
\text { digunakan meliputi laptop, materi ajar } \\
\text { (power point), whatsapp yang terkoneksi } \\
\text { dengan internet, presensi peserta didik, } \\
\text { 3. H-1 kegiatan pembelajaran, mengintruksikan } \\
\text { peserta didik mengisi soal pre-test terlebih } \\
\text { dahulu. } \\
\text { 4. Menerapka kolaborasi penerapan WhatsApp } \\
\text { group group dan linoit dalam pembelajaran } \\
\text { pengelolaan dana kas kecil } \\
\text { 5. Materi yang digunakan yaitu pengelolaan kas } \\
\text { kecil }\end{array}$ & \\
\hline $\begin{array}{l}\text { Tindakan } \\
\text { (Action) }\end{array}$ & $\begin{array}{l}\text { Apersepsi, motivasi, penyampaian tujuan } \\
\text { - Guru memberi salam dan menyapa peserta } \\
\text { didik. } \\
\text { - Guru menanyakan kondisi peserta didik. } \\
\text { - Guru membuka pelajaran dengan melakukan } \\
\text { doa bersama yang dipimpin oleh salah } \\
\text { seorang peserta didik. } \\
\text { - Guru mengecek kehadiran peserta didik. } \\
\text { - Guru mengecek dan menginstruksikan } \\
\text { kembali peserta didik yang belum mengisi } \\
\text { soal pre-test. } \\
\text { Guru memberikan motivasi belajar kepada } \\
\text { peserta didik. } \\
\text { Guru menyampaikan manfaat materi } \\
\text { pembelajaran pengelolaan kas dalam } \\
\text { kehidupan sehari-hari } \\
\text { Guru menyampaikan kompetensi, lingkup } \\
\text { materi dan tujuan pembelajaran yang akan } \\
\text { dicapai peserta didik. }\end{array}$ & \begin{tabular}{ll} 
- & \multicolumn{2}{l}{ Pembelajaran } \\
tatap muka & (waktu relative \\
singkat) untuk \\
membahas yang \\
tidak bisa \\
dijelaskan di wa \\
group \\
- Pembelajaran \\
daring. \\
- Materi dan tugas \\
ada dalam bentuk \\
power point \\
dikirim lewat \\
WhatsApp group \\
group \\
Diskusi melalui \\
wa group
\end{tabular} \\
\hline & $\begin{array}{l}\text { Menyajikan informasi } \\
\text { - Guru memperlihatkan contoh metode } \\
\text { pengelolaan dana kas kecil } \\
\text { - Guru memberikan pertanyaan mendasar } \\
\text { mengenai topik yang sesuai dengan realita } \\
\text { dunia nyata kepada peserta didik. } \\
\text { - Apakah peserta didik pernah memikirkan } \\
\text { Bagaimana perusahaan melakukan } \\
\text { pencatatan kas } \\
\text { - Mengapa perlu dilakukan pencatatan yang } \\
\text { - } \text { tepat? } \\
\text { Guru mengintruksikan peserta didik untuk }\end{array}$ & \\
\hline
\end{tabular}




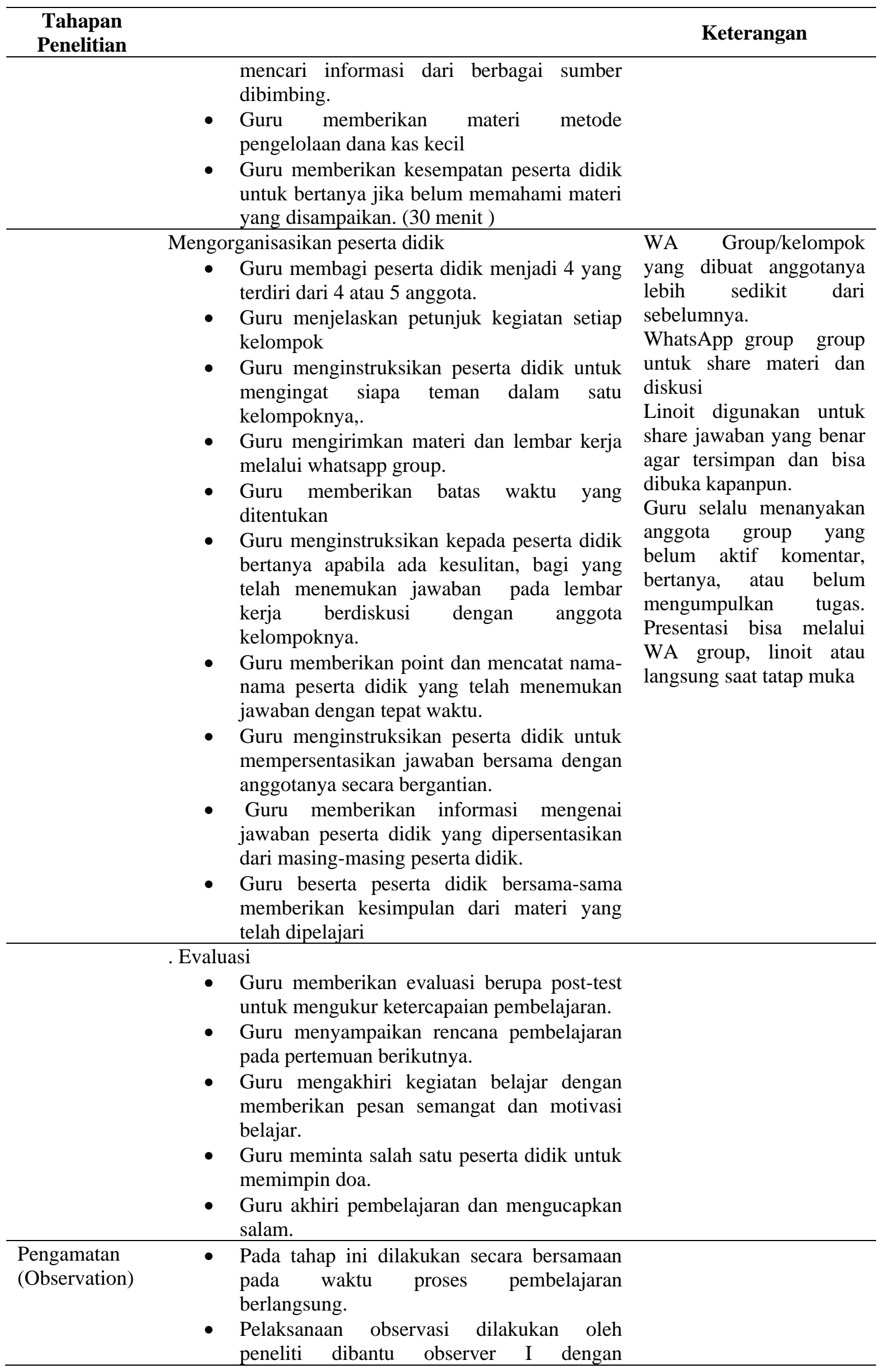


Penerapan Media Whatsapp Group dan Linoit dalam Meningkatkan Hasil Belajar Pengelolaan Kas Kelas XI Perbankan SMK Negeri 1 Singkep Di Masa Pandemic

Covid-19

\begin{tabular}{ll}
\hline $\begin{array}{c}\text { Tahapan } \\
\text { Penelitian }\end{array}$ & Keterangan \\
\hline & menggunakan lembar observasi untuk \\
& mengetahui aktivitas guru dan peserta didik \\
& selama proses pembelajaran \\
\hline -Refleksi & Hasil refleksi digunakan untuk menetapkan \\
(Reflexy) & langkah selanjutnya dalam upaya untuk \\
& menghasilkan perbaikan pada siklus \\
& selanjutnya. Data hasil observasi dan hasil \\
& belajar peserta didik (pre-test dan post-test) \\
& kemudian dianalisis sebagai data kajian \\
& untuk melakukan refleksi, sehingga dapat \\
& diketahui perkembangan yang diperoleh dari \\
& kolaborasi penerapan WhatsApp group dan \\
& linoit \\
\hline
\end{tabular}

\section{Kesimpulan}

Berdasarkan hasil penelitian dan pembahasan diatas dapat disimpulkan sebagai berikut. Penerapan media WhatsApp dan Linoit dapat meningkatkan hasil belajar siswa, Hal ini dapat dilihat dari nilai masing-masing individu. Rata-rata setiap siklus I adalah 64,95 dan meningkat menjadi 82,81 pada siklus II dan terdapat 19 siswa nilainya meningkat, 2 siswa dengan nilai tidak tuntas. Dari hasil tersebut diperoleh ketuntasan belajar $90,5 \%$. 
Sri Kartini

\section{BIBLIOGRAFI}

Adawiyah, Dwi Putri Robiatul, \& Kadir, Nurhaya. (2020). Analisis Peran Media dalam Upaya Pencegahan Penyebaran Virus Corona (Covid-19) di Indonesia. Jurnal Mediakita: Jurnal Komunikasi Dan Penyiaran Islam, 4(1).Google Scholar

Badaruddin, Achmad. (2015). Peningkatan motivasi belajar siswa melalui konseling klasikal. CV Abe Kreatifindo. Google Scholar

Jumiatmoko, Mr. (2016). Whatsapp messenger dalam tinjauan manfaat dan adab. Wahana Akademika: Jurnal Studi Islam Dan Sosial, 3(1), 51-66. Google Scholar

Kurniati, Ika, \& Nuroso, Harto. (2020). Peningkatan hasil belajar peserta didik pada pembelajaran tematik kelas 1 tema 4 sub tema 2 melalui pembelajaran zoom dengan menggunakan media power point sekolah dasar negeri 01 lambur kecamatan kandangserang kabupaten pekalongan tahun pelajaran 2020/2021. JP3 (Jurnal Pendidikan Dan Profesi Pendidik), 6(1). Google Scholar

Kusumaningrum, Putri. (2012). Penggunaan Model Pembelajaran Kooperatif Tipe Numbered Head Together (NHT) Dengan Pemberian Tugas Untuk Meningkatkan Hasil Belajar Akuntansi Pada Siswa Kelas X. 2 SMK Negeri 1 Karanganyar Tahun Pelajaran 2011/2012. Google Scholar

Lie, Anita. (2012). Cooperative Learning. Jakarta: PT Gramedia.

Marina, Anna, Wahjono, Sentot Imam, \& Suarni, Agusdiwana. (2018). Sistem informasi akuntansi: teori dan praktikal. UMSurabaya Publishing.

Miaz, Yalvema. (2014). Penelitian tindakan kelas bagi guru dan dosen. Google Scholar

Musfah, Jejen. (2018). Manajemen pendidikan aplikasi, strategi, dan inovasi. Prenada Media. Google Scholar

Naila, Rahma Jamilah. (2021). Pembelajaran Matematika Semester Ganjil Selama Pandemi Covid-19 Di Mts Al-Hidayah Purwokerto Utara. Iain Purwokerto. Google Scholar 
Penerapan Media Whatsapp Group dan Linoit dalam Meningkatkan Hasil Belajar Pengelolaan Kas Kelas XI Perbankan SMK Negeri 1 Singkep Di Masa Pandemic

Purandina, I. Putu Yoga. (2020). 'Plus-Minus'pembelajaran Daring Bahasa Inggris Selama Pandemi Covid-19. Pengalaman Pembelajaran Bahasa Inggris Daring Di Perguruan Tinggi Pada Masa Pandemi Covid-19, 18. Google Scholar

Purba, Ridwin, Asnewastri, Asnewastri, Hutauruk, Ahmad Fakhri, Ginting, Andres M., \& Resmi, Resmi. (2021). Pelatihan Pembelajaran Online Pada Masa Pandemi Covid-19 Bagi Guru-Guru Anggota Kn-Lwf Pematangsiantar. Community Development Journal: Jurnal Pengabdian Masyarakat, 2(2), 359-368. Google Scholar

Santoso, Budi. (2010). Skema dan mekanisme pelatihan: panduan penyelenggaraan pelatihan. Yayasan Terumbu Karang Indonesia. Google Scholar

Wardhani, Rizky Amalia, \& Muid, Dul. (2017). Pengaruh Agresivitas Pajak, Ukuran Perusahaan Dan Profitabilitas Terhadap Corporate Social Responsibility (Studi Empiris Pada Perusahaan Manufaktur Yang Terdaftar di Bursa Efek Indonesia Tahun 2014-2015). Diponegoro Journal of Accounting, 6(3), 752-761. Google Scholar

Copyright holder :

Sri Kartini (2021)

First publication right :

Syntax Idea

This article is licensed under:

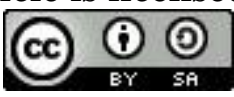

